\title{
The Effect Of Punishment On Employee Productivity In Pt. Asuransi Bintang TBK Makassar Branch
}

\author{
Nurlina \\ Lecturer, Department of Management \\ STIMI-YAPMI Makassar, South- Sulawesi, Indonesia \\ Anwar Ramli \\ Lecturer, Department of Management, Faculty of Economyy \\ State University of Makassar South Sulawesi, Indonesia
}

\begin{abstract}
This study aims to determine the magnitude of the influence of Punishmant on employee productivity at PT. Asuransi Bintang Tbk. Makassar branch. The population in this study were all employees of PT. Asuransi Bintang Tbk. Makassar branch, amounting to 25 people. The number of samples used was 25 people using saturated sample toeri. Data collection was carried out using interview, observation and questionnaire methods. The data analysis technique used is simple regression analysis using Statistical Product Standard Solution (SPSS) for window. This shows that punishment has a significant effect on employee work productivity at PT. Asuransi Bintang Tbk. Makassar branch.
\end{abstract}

Keywords: Punishment and Work Productivity of Employees

\section{INTRODUCTION}

PT. Asuransi Bintang Tbk is one of the most experienced general insurance companies in Indonesia which was founded on March 17, 1955 by Soedarpo Sastrosatomo, a former Indonesian independence fighter of the Republic of Indonesia. This company has employees who are disciplined enough in carrying out their duties so that it can support the continuity of the company. It is realized that employees and companies are two things that cannot be separated. Employees play the main role in running the company and active actors in every activity of the organization. The wheel of a good corporate life is if the company has good employee performance. Therefore, the performance appraisal is very necessary to be done by the company to determine the extent to which employees are able to play a role in the company's development and growth.

In achieving its objectives the company is strongly influenced by employee performance. In the process of achieving good performance, there are several things that must be considered and one of them is sanctions or penalties that force employees to keep promises or comply with the rules that apply to the company concerned. Punishment is a punishment given to employees because of violations of applicable rules. In a company sanctions are given to employees who are negligent or make mistakes that can harm the company. Sanctions can be given in the form of reprimands, warning letters of suspension and even termination or termination of employment. In undergoing 
Nurlina, \& Ramli, A. (2020) The Effect of Punishment on Employee Productivity In Pt. Asuransi Bintang TBK Makassar Branch. Archives of Business Research, 8(4). 95-104.

punishment or sanctions, the parties concerned namely employers and workers must know the rights and obligations of each party.

With the imposition of sanctions that are applied in the case of a major company at PT Asuransi Bintang Tbk. Makassar Branch requires employees to produce work productivity by seriously carrying out their work, especially in producing output as big as PT. Asuransi Bintang Tbk. The application of witnesses or punishment at PT. Asuransi Bintang Tbk. Makassar branch, is expected to be able to describe the motivation and threats to its employees in producing work productivity in accordance with what is expected by the company itself.

\section{LITERATURE REVIEW}

In principle, punishment is anything that can weaken behavior and tends to reduce the frequency of subsequent behavior and can consist of requests and unexpected consequences. So in general sanctions or punishment is torture that is given to someone who makes a certain mistake or violation such as a violation of the law and so on. Based on this statement, it can be explained that sanctions are a consequence that does not please the response of certain behaviors with the aim of weakening the behavior and reducing the frequency of subsequent behavior. Dessyana (2004: 6) divides sanctions or punishments into two types, firstly a preventative sanction namely sanctions carried out with the intention or so that no violations occur, these sanctions intend to prevent violations from occurring, so this is done before violations occur. Examples of orders, prohibitions, agreements, supervision. The second is repressive sanctions, namely sanctions carried out because of violations, by the sin that has been done. So the sanctions occur after an error occurs. One of the penalties given by companies to employees is termination of employment.

Termination of employment is the dismissal or removal of an employee or employee from the work environment either on his own personal initiative or by force the company where he works. Voluntary dismissal is usually in the form of resignation or retirement, whereas forcibly forms such as temporary or permanent dismissal, aka dismissal.

Manulang cited Fridayanti (2013: 1-2) as saying that the termination of employment can provide several meanings, namely, first, Termination, termination of employment due to the completion or termination of an agreed work contract. Second, Dismissal, the termination of employment due to employees committing violations of the established discipline. Third, Redundancy, because the company is developing it using new technology machines, such as: the use of industrial robots in the production process, the use of heavy equipment that is sufficiently operated by one or two people to replace a number of workers. This results in a reduction in labor. Fourth, Retcheck, which is associated with economic problems, such as an economic recession that makes companies unable to provide wages to their employees.

Sanctions must be based on reasons or arguments based on law and facts. According to Manullang, Ardana was quoted (2012: 276-277); there are 3 main causes that result in punishment, that is, incompetence in the trial period. In the trial period which is a maximum of 3 months, an employee or employee can be given instantly without regard to the one month grace period as described earlier. Then subject to punishment by the judge or the authorities. Employees who are in the process of determining sanctions in the form of termination of employment and being detained by 
the authorities continuously \pm 2 years are not due to traffic accidents so that they cannot do work as they should only be given fixed income.

If the employee is sick or suffers from continuous illness \pm 2 years, the company can impose sanctions on the employee concerned. But in the period of illness and unable to work, the possibility of the company reducing the amount of salary / wages can be done for example: the first month of reduction: $0 \%$, the second month: $20 \%$, the third month: $20 \%$ again and the fourth month as well: $20 \%$ so in the fourth month, living salary: $40 \%$ of all salary received. However, employees who experience such treatment are still entitled to get severance pay or service fees according to their tenure.

Employees who are legally proven to have committed disciplinary violations with a classification of minor disciplinary violations in the form of recorded oral reprimands that are in effect for 3 (three) months, so if they are undergoing such disciplinary sanctions, the employee concerned commits disciplinary violations with the classification of minor disciplinary violations, then is subject to light disciplinary sanctions in the form of the first written warning, which is valid for 6 months. Crime. Employees who are proven to have committed theft, fraud or other crimes that endanger the company.

There is also a function of threat or punishment that is carried out, among others, by measuring the level of seriousness of the violations deemed by management. Limiting behavior, preventing repetition of unexpected behavior. Shows the position of subordinate employees in the series of sanctions. Strengthen motivation to avoid unexpected behavior.

Cameron cited Timpe (1999: 136) argues that sanctions imposed on violators of the rules, in principle aim to warn employees clearly about the behavior required and the consequences of violations that can continue. Furthermore, if we discuss the work productivity of employees for a company is very important as a measure of success in running a business. Because the higher the work productivity of employees in the company, it means that the company's profits and productivity will increase. Wibowo (2011: 110) argues that productivity is often measured in terms of economic inputs and outputs. However, the input and output of human and social resources is also an important factor. If organizational behavior is better, it can improve job satisfaction resulting in an increase in human resource outcomes.

According to Komarudin quoted by Ardana (2012: 269), stated that; "Productivity is the ability to produce goods or services that are usually calculated per hour, per month, per machine, per other production factors". According to Sinungan quoted by Nensy (2004: 14) the notion of productivity is grouped into three namely first, the traditional formula for overall productivity is nothing but the ratio of what is produced to the overall equipment, Second, Productivity is basically a mental attitude that always has the view that the quality of life today is better than yesterday, and tomorrow is better than today. Third, Productivity is a harmonious integrated interaction of three essential factors, namely investment including the use of knowledge and technology as well as research, management and labor. Furthermore, this research framework is as follows: 


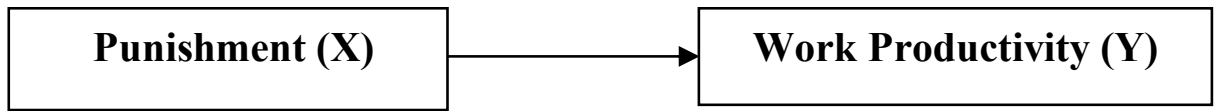

Figure 1: Schematic Framework

\section{RESEARCH METHOD}

In this study two types of variables are used that have a relationship between one variable with another variable, namely punishment as an independent variable and employee work productivity as a dependent variable.

Table 1. Variables and Indicators of Punishment

\begin{tabular}{ll}
\hline Independent Variable $(\mathbf{X})$ & \multicolumn{1}{c}{ Indicators } \\
\hline & 1. Termination of employment \\
Punishment & 2. Letter of reprimand \\
& 3. Exposed to a fine. \\
& 4. Wage deductions \\
& 5. Compensation \\
\hline
\end{tabular}

Table2. Variables and Indicators of Work Productivity

\begin{tabular}{lll}
\hline Dependent Variable (Y) & \multicolumn{1}{c}{ Indicators } \\
\hline & 1. & Education and skills. \\
& 2. & Motivation. \\
Labor Productivity & 3. & Health \\
& 4. & Work environment \\
& 5. & Opportunities for \\
& & achievement \\
\hline
\end{tabular}

In this study as many populations as well as samples. 25 employees from various fields respectively in the company PT. Asuransi Bintang Tbk Makassar Branch. The analytical method used to determine the magnitude of the relationship and the effect of independent variables on the dependent variable, the SPSS 21 program is used.

\section{RESULT}

The data presented in this study are data obtained from questionnaires in the form of statements related to the object in this study, namely variable X (punishment) and variable Y (work productivity). Each respondent has a total score of each of the two variables studied. Furthermore, the data obtained from the results of direct research and have been obtained from each of the respondents who were sampled in this study, to analyze the data that has been obtained from the results of this study are used computer software with SPSS 21 for Windows program that aims to find out how much influence between punishment with employee productivity can be seen from the following calculations that will be described by researchers. Punishment, is an unpleasant consequence of the response of certain behaviors with the aim to weaken the behavior. Sanctions can be in the form of prefentive sanctions, namely sanctions carried out with the intent to prevent 
violations such as orders, prohibitions, agreements, and supervision, while repressive sanctions are sanctions carried out because of violations. So the sanctions occur after a violation.

The following are data obtained from respondents' answers regarding Punishment PT. Asuransi Bintang Tbk. Makassar branch.

Table 2: Respondents Response To Punishment

\begin{tabular}{|c|c|c|c|c|c|c|c|c|}
\hline \multirow[t]{2}{*}{ No } & \multirow[t]{2}{*}{ Statement } & \multicolumn{4}{|c|}{$\begin{array}{c}\text { Level of Respondents' } \\
\text { Answers } \\
\end{array}$} & \multirow{2}{*}{$\begin{array}{c}\text { Frequenc } \\
\mathbf{y}\end{array}$} & \multirow[t]{2}{*}{ Score } & \multirow[t]{2}{*}{ Index } \\
\hline & & 4 & 3 & 2 & 1 & & & \\
\hline 1 & 2 & \multicolumn{4}{|c|}{3} & 4 & 5 & 6 \\
\hline 1. & $\begin{array}{l}\text { Employees violate the discipline that } \\
\text { has been set by the company. }\end{array}$ & 11 & 12 & 1 & 1 & 25 & 83 & 20,7 \\
\hline 2. & $\begin{array}{l}\text { Employees who commit violations } \\
\text { will be given a warning. }\end{array}$ & 14 & 6 & 2 & 3 & 25 & 81 & 20,2 \\
\hline 3. & $\begin{array}{l}\text { Employees who commit violations } \\
\text { because they do not reach the target. }\end{array}$ & 15 & 8 & 2 & 0 & 25 & 88 & 22 \\
\hline 4. & $\begin{array}{l}\text { Employees who take actions that } \\
\text { harm the company in accordance with } \\
\text { existing provisions. }\end{array}$ & 14 & 6 & 5 & 0 & 25 & 84 & 21 \\
\hline 5 & $\begin{array}{l}\text { Employees who make negligence and } \\
\text { mistakes that result in damage / loss } \\
\text { of company assets. }\end{array}$ & 12 & 11 & 1 & 1 & 25 & 84 & 21 \\
\hline & Amount & & & & & & & \\
\hline & Average & & & & & & 26 & \\
\hline
\end{tabular}

Source; Processed Data (2020)

The results of the table above regarding the respondent's response to the variable shows the value with an average score of $26.22 \%$ where the highest index of all the indicators of variable $\mathrm{X}$ is found in the statement item indicator "Affected Fines" increases flexibility with the acquisition index level of respondents' answers by $22 \%$. And the lowest index value is found in the "Letter of Reprimand" item by obtaining an index of $20.2 \%$.

\section{Work Productivity of Employee}

Productivity can be seen from the relationship between the results and the time needed to complete them. The shorter the time needed to achieve the desired results, the more system increases. Productivity can be different for different people, but it is designed to produce different qualities. 
Nurlina, \& Ramli, A. (2020) The Effect of Punishment on Employee Productivity In Pt. Asuransi Bintang TBK Makassar Branch. Archives of Business

Table 3 : Respondents Response to Employee Productivity.

\begin{tabular}{|c|c|c|c|c|c|c|c|c|}
\hline \multirow{2}{*}{ No } & \multirow{2}{*}{ Statement } & \multicolumn{4}{|c|}{ Respondents Response Rate } & \multirow{2}{*}{$\begin{array}{c}\text { Frequenc } \\
y\end{array}$} & \multirow{2}{*}{ Score } & \multirow{2}{*}{ Index } \\
\hline & & 4 & 3 & 2 & 1 & & & \\
\hline 1 & 2 & & 3 & & & 4 & 5 & 6 \\
\hline 1. & $\begin{array}{l}\text { Educated and skilled workers are } \\
\text { easier to understand the results they } \\
\text { want to do. }\end{array}$ & 15 & 9 & 0 & 1 & 25 & 88 & 22 \\
\hline 2. & $\begin{array}{l}\text { I am very passionate in carrying out } \\
\text { work. }\end{array}$ & 8 & 8 & 7 & 2 & 25 & 72 & 18 \\
\hline 3. & $\begin{array}{l}\text { Physical strength is needed in carrying } \\
\text { out work. }\end{array}$ & 7 & 9 & 7 & 2 & 25 & 71 & 17,7 \\
\hline 4. & $\begin{array}{l}\text { The work environment is quite } \\
\text { instrumental, so that employees can } \\
\text { work quietly and comfortably. }\end{array}$ & 17 & 4 & 2 & 2 & 25 & 86 & 21 \\
\hline 5. & $\begin{array}{l}\text { Employee opportunity to excel is very } \\
\text { necessary in employee development. }\end{array}$ & 21 & 4 & 0 & 0 & 25 & 96 & 24 \\
\hline & Amount & & & & & & & 103 \\
\hline & Average & & & & & & & 25,68 \\
\hline
\end{tabular}

Source; Processed Data (2020)

The results of the table above regarding the responses of respondents to the variable work productivity shows the average score of $25.68 \%$. It can be seen that the highest index value of all indicators of "achievement opportunity" with the acquisition index of the respondent's answer rate of $24 \%$, and the lowest index value is found in the statement item "Health" with the acquisition of an index of $17.7 \%$.

\section{Validity Test and Reliability}

\section{THE ANALYSIS OF HYPOTHESIS TESTING}

Table 4: The Validity Test Results of X Variable

\begin{tabular}{|c|c|c|c|}
\hline Indicators & r value & r table & information \\
\hline Punishment & & & \\
X1.1 & 0,619 & 0,396 & Valid \\
X1.2 & 0,732 & 0,396 & Valid \\
X1.3 & 0,609 & 0,396 & Valid \\
X1.4 & 0,619 & 0,396 & Valid \\
X1.5 & 0,612 & 0,396 & Valid \\
\hline
\end{tabular}

Source; Data processed by SPSS 21 (2020)

The results of testing the validity of the questionnaire items showed that all question items in each $\mathrm{X}$ variable had a correlation value above 0.3 as the boundary value of a research questionnaire item 
said to be acceptable (acceptable). So it can be said that the variable questionnaire item (X) is valid and can be used to measure the variables studied.

Table 5; The Reliability Test Results of X Variable

Reliability Statistics

\begin{tabular}{llr}
\hline Cronbach's Alpha & N of Items & 5 \\
\hline & .678 & \\
\hline
\end{tabular}

Source; SPSS Processed Data (2020)

Danang Sunyoto (2012: 70) announced that "The reliability test shows that an instrument can be trusted enough to be used as a data collection tool because the instrument is already good. A good instrument does not direct respondents to choose certain answers. Reliable instruments that are reliable can produce reliable data too. If the statements are valid and reliable, these items can be measured, the questionnaire items are said to be reliable if Cronchbach's alpha> 0.60 and said to be non-reliable if Croncbach's alpha $<0.60$. Based on the reliability test in the table above shows that the resulting instrument is perfect or can be seen from the alpha value of 0.678 . This value is the overall reliability value, the higher the value means the more reliable.

Table 6; TheValidity Test of Y Variable

\begin{tabular}{|c|c|c|c|}
\hline Indicators & r value & r table & information \\
\hline Work productivity & & & \\
X1.1 & 0,697 & 0,396 & Valid \\
X1.2 & 0,752 & 0,396 & Valid \\
X1.3 & 0,730 & 0,396 & Valid \\
X1.4 & 0,633 & 0,396 & Valid \\
X1.5 & 0,635 & 0,396 & Valid \\
\hline
\end{tabular}

Source; SPSS Processed Data Results (2020)

The results of testing the validity of the questionnaire items indicate that all statement items in each variable (Y) have a correlation value above 0.3 as the boundary value of an item the research questionnaire can be used (acceptable). so it can be said that the questionnaire item Work productivity variable (Y) is valid and can be used to measure the examined variables.

Table 7; The Reliability Test Results Of Y Variable Reliability Statistics

\begin{tabular}{llll}
\hline Cronbach's Alpha & N of Items & \\
\hline & .656 & 5 \\
\hline
\end{tabular}

Source; SPSS Processed Data Results (2020).

The reliability test is useful to determine whether the instrument in which the questionnaire can be used more than once, at least by the same respondent will produce consistent data. In other words, instrument reliability characterizes the level of consistency. According to Suharmisi Danang 
(2010: 70) quoted "Questionnaire items are said to be reliable (feasible) if Cronbach's alpha> 0.60 and said to be not reliable if Cronbach's alpha <0.60". Based on the reliability test results in the picture above shows that the results of the instrument produced perfect or acceptable bias seen from the alpha value of 0.656 . This value is the overall reliability value, the higher the value means the more reliable.

\section{The Analysis Results of Simple Regression}

Table 8; Simple Regression Equation Data

Coefficients

\begin{tabular}{|l|r|r|r|r|r|}
\hline \multirow{2}{*}{ Model } & \multicolumn{2}{|c|}{$\begin{array}{c}\text { Unstandardized } \\
\text { Coefficients }\end{array}$} & \multicolumn{1}{c|}{$\begin{array}{c}\text { Standardized } \\
\text { Coefficients }\end{array}$} & \multirow{2}{*}{ Sig. } \\
\cline { 2 - 4 } & \multicolumn{1}{|c|}{ B } & \multicolumn{1}{c|}{ Std. Error } & \multicolumn{1}{c|}{ Beta } & & \\
\hline (Constant) & 16.187 & 3.614 & & 4.479 & .000 \\
Punishmant & .739 & .213 & .738 & 4.182 & .857 \\
\hline
\end{tabular}

a. Dependent Variable: Productivity

Source; SPSS Processed Data Results (2020).

From table 8 a correlation coefficient can be made where the $\alpha$ value obtained is 16.187 and the large value of 0.739 is then entered in the equation proposed by Sugiono (2007: 261), where (Y= $\alpha+b X)$.

$$
Y=16,187+0,739 X
$$

From this equation can be interpreted that every increase in punishment (X) by $1 \%$ there will be an increase in work productivity by 0.739 this means if the percentage of punishment level (X) increases, the percentage of the level of work productivity will also increase by 0.739 .

\section{Correlation Coefficient Analysis}

Table 9; Correlation Coefficient Analysis Results

\begin{tabular}{ccccc}
\hline Model & $R$ & $R$ Square & Adjusted $R$ Square & Std. Error of the Estimate \\
\hline 1 & $.638^{\mathrm{a}}$ & .558 & .052 & 2.218 \\
\hline
\end{tabular}

a. Predictors: (Constant), Punishment

b. Dependent Variable: Produktivitas

Source; SPSS Processed Data (2020)

From the results of the analysis obtained correlation ( $\mathrm{r}$ ) of 0.638 or $63.8 \%$ the value indicates that the relationship between employee productivity is "strong" according to conservative rules of interpretation interpretation that if the value of $0.60-0.799$ then the correlation "strong" is stated Sugiono (2007: 213). While the magnitude of the contribution of influence on employee work productivity can be seen from the value of R Square (R2) in table 12 shows that the amount of work 
productivity of employees is 0.558 or $55.8 \%$ which means that the effect of punishment on work productivity is $55.8 \%$ while the rest $44.2 \%$ is influenced by other factors not examined.

\section{T-Test Analysis}

The t-test is intended to measure the amount of influence directly from the punishment variable on employee work productivity. based on the calculation result data in table 11 obtained $\mathrm{t}$-value $=$ 4.182. by using a real level of $0.05(\alpha=0.05)=\alpha / 2=0.05 / 2=0.025$ then obtained $\mathrm{dk}=\mathrm{n}-2$ (252 ), then $\mathrm{dk}=23$ and the value of $\mathrm{t}$-table $=2.068$ so that it can be obtained $t$-value greater than the t-table $(4.182>2.068)$.

The testing decision on the proposed hypothesis is if t-count is greater or equal to t-table and the probability value is smaller than the real level $\alpha=0.05$, then it can be said that punishment has a significant effect on employee productivity at PT. Asuransi Bintang Tbk. Makassar branch. Conversely, if the t-count is smaller than the t-table or the probability is greater than the real level $\alpha=0.05$, it can be said that punishment has no significant effect on employee productivity at the office of PT. Asuransi Bintang Tbk. Makassar branch.

Based on the above requirements, the answer to the hypothesis raised earlier that "punishment has a significant effect on work productivity at PT. Asuransi Bintang Tbk. It has been proven or in other words the hypothesis is accepted.

\section{CONCLUTION}

Based on research that has been observed that the application or imposition of sanctions on PT. Asuransi Bintang Tbk. Makassar branch. Employees do not know the rules regarding the provision of witnesses or punishment that has been agreed upon previously. Conditions regarding the application of the results of the correlation coefficient analysis obtained correlation ( $\mathrm{r}$ ) of 0.638 or 63.8 values indicate that the relationship between punishment on employee productivity is "strong" according to conservative rules of correlation interpretation if the value is $0.60-0.799$ then the correlation is strong Conditions of the application of punishment in PT. Asuransi Bintang Tbk. Makassar branch from the results of a simple regression equation, if it has an increase of $1 \%$, there will be an increase in work productivity by 0.739 , this means that if the percentage of punishment levels increase with the application of the results of the hypothesis t-test "Punishment has a significant effect on employee productivity at PT. Asuransi Bintang Tbk. Makassar branch ", it has been proven and the hypothesis is accepted.

\section{RECOMMENDATION}

Ideally sanctions are not only known by the leader (manager), but employees must know the system of sanctions that have been applied in the company. The relationship between all parties in giving sanctions needs to be improved, both in terms of communication and coordination, so that nothing is desired. Researchers suggest, with sanctions or employee productivity can be increased in order to achieve organizational goals.

\section{References}

Agussalim, 1990. The Termination of Employment and Settlement. Medan: Unismuh Sutra.

Anoraga, Pandji. 2005. Business Management. Third Matter. Jakarta. Rineka Cipta. 
Nurlina, \& Ramli, A. (2020) The Effect of Punishment on Employee Productivity In Pt. Asuransi Bintang TBK Makassar Branch. Archives of Business Research, 8(4). 95-104.

Ardana, I komang, et al. 2012. Human Resource Management. Yogyakarta: Graha Ilmu.

Arikunto S, 2006. Research Procedure A Practical Approach. Jakarta: Rineka Cipta.

Desyyana, 2014. Work Termination. Jakarta: Student Unej.

Fridayanti, Atika. 2013. Punishment Sanctions. Jakarta: Wordprees.

Hasibuan, Malayu S.P. 1998. Human Resource Management. Jakarta: Bumi Aksara.

Kusriyanto. 1991. Strategic Human Resource Management. Jakarta: Ghalia Indonesia.

Mangkuprawira. 2009. Human Resource Management. Bandung: Rona Wajah

Nasution. 2004. Personnel Management. Jakarta: Djambatan.

Nensy, 2004. The Role of Education and Training in Increasing Employee Work Productivity. Makassar: UNM.

Siagian. 2014. Human Resource Management. Jakarta: Bumi Aksara

Sugiyono, 2004. Statistics for Research. Bandung: Alfabeta

Sunyoto Danang, 2011. Human Resource Management. Yogyakarta: CAPS (Center for Academic Publishing Service).

Sunyoto Danag, 2011. Methodology for Research. Yogyakarta: CAPS (Center for Academic Publishing Service).

Timpe. 1999. Imposition of Sanctions. Semarang: Universitas Diponegoro Semarang.

Wibowo, 2011. Performance Management-Third Edition. Jakarta: Raja Grafindo Persada

Winaya Kuna. 1989. Employee Productivity. Jakarta: Graha Ilmu 